\title{
ESTABLISHING AN OMBUDS FUNCTION: THE ASIAN DEVELOPMENT BANK APPROACH AND LESSONS LEARNED FOR OTHER INTERNATIONAL FINANCIAL ORGANISATIONS
}

\author{
Suresh Nanwani*
}

\begin{abstract}
Over recent years, many organisations, both public and private, have been establishing an ombuds function as an informal conflict resolution mechanism to resolve work-place disputes and concerns. This article examines the establishment of conflict resolution mechanisms in international financial organisations (IFOs) including the World Bank Group and the major regional development banks in Africa, Asia, Latin-America, and Europe. The article examines the Asian Development Bank's approach in establishing an ombuds function. The article concludes with suggestions in moving forward of the ombuds offices in the IFOs and the lessons learned for other IFOs.
\end{abstract}

Advisor, Asian Development Bank; Visiting Professorial Fellow, University of New South Wales; Research Fellow at Birkbeck, University of London. Email: snanwani@adb.org. The author thanks Professor Leslie Moran, Birkbeck, University of London for providing comments on this article and Associate Professor Dr. A. Mohaimin Ayus, Dean of the Faculty of Shariah and Law, Universiti Islam Sultan Sharif Ali, Brunei Darussalam, for assistance in the Malay language translation of this article. The author also thanks Ms. Lalaine Danao and Ms. J.V. Husmillo for their research assistance. The views expressed in this article are those of the author and do not reflect the views of the Asian Development Bank. 
Keywords: ombuds, informal conflict resolution, mediation, international financial organisations, stakeholders, Asian Development Bank.

\title{
MENUBUHKAN FUNGSI OMBUDS: PENDEKATAN BANK PEMBANGUNAN ASIA DAN PENGAJARAN YANG DIPELAJARI DARI ORGANISASI-ORGANISASI KEWANGAN ANTARABANGSA YANG LAIN
}

\begin{abstract}
ABSTRAK
Dalam beberapa tahun kebelakangan ini, banyak organisasi, sama ada dalam sektor awam atau swasta, telah menubuhkan fungsi ombuds sebagai mekanisme penyelesaian konflik bagi memutuskan perbalahan dan permasalahan berkaitan tempat kerja. Artikel ini meneliti penubuhan mekanisme-mekanisme penyelesaian konflik dalam organisasi-organisasi kewangan antarabangsa (IFO) termasuk Kumpulan Bank Dunia (World Bank Group) dan bank-bank pembangunan serantau yang besar di Africa, Asia, Amerika-Latin, dan Eropah. Artikel ini juga akan meneliti pendekatan Bank Pembangunan Asia (ADB) dalam menubuhkan fungsi ombuds. Artikel ini diakhiri dengan cadangan-cadangan bagaimana pentadbiran ombuds harus bergerak maju ke hadapan dalam organisasi-organisasi kewangan antarabangsa (IFO) dan pengajaran-pengajaran yang dapat dipelajari dari organisasi-organisasi kewangan antarabangsa yang lain.
\end{abstract}

Kata kunci: ombuds, penyelesaian pertikaian tak formal, mediasi, organisasi kewangan antarabangsa, pemegang kepentingan, Bank Pembangunan Asia. 


\section{INTRODUCTION AND ESTABLISHMENT OF CONFLICT RESOLUTION MECHANISMS}

International financial organisations (IFOs) such as multilateral development banks (MDBs) ${ }^{1}$ and the International Monetary Fund (IMF), as well as the United Nations (UN) and its agencies, have under their charters immunity from judicial proceedings in national legal systems on employment matters. ${ }^{2}$ With this immunity, conflict resolution systems were developed as elaborated in the next paragraph. The focus of this article is on the IFOs - the MDBs and the IMF. The first part of this article is on the establishment of conflict resolution systems in IFOs. The second part deals with the introduction of ombuds services in the IFOs and ADB's approach in establishing its ombuds function. The article concludes with suggestions for moving forward of the ombuds offices in the IFOs and the lessons learned that can be applied for other IFOs.

To resolve employment disputes, IFOs established conflict resolution mechanisms, whether by way of formal process, such as a peer-review appeal system in the institution or an administrative tribunal vested by the institution's board of directors with judicialmaking power to award damages, or by an informal process such as an ombuds function ${ }^{3}$ or mediation services, as illustrated in Table 1.

These are the World Bank, that is, the International Bank for Reconstruction and Development (IBRD) and the concessional lending window, the International Development Association (IDA), and the four major regional development banks for Africa, Asia and the Pacific, Europe, and Latin America: the African Development Bank (AfDB); the Asian Development Bank (ADB); the European Bank for Reconstruction and Development (EBRD); and the InterAmerican Development Bank (IADB). The term "World Bank Group" (WBG) refers to the World Bank, International Finance Corporation, Multilateral Investment Guarantee Agency, and the International Centre for Settlement of Investment Disputes

2 For a fuller discussion on the immunity of international organisations in national courts, see Amerasinghe, C. F., The Law of the International Civil Service 2nd Revised ed. Vol I, (Oxford University Press, 1994), 42-44.

3 The term "ombuds function" (also referred to as "ombuds services") is used in this article, and this term also refers to the ombudsperson or ombudsman as IFOs have used varying terms. The exact term varies 
The UN also established its conflict resolution mechanism, as provided in Table 1, and overhauled its existing system of administration of justice of more than 60 years with a new system which became operational in July 2009. ${ }^{4}$ In contrast with the IFOs which took a far longer time to set up administrative tribunals, the UN set up its Administrative Tribunal within 5 years of its establishment. The question of the establishment of an UN administrative tribunal was considered as early as 1945 by the Preparatory Commission of the UN and by its Executive Committee to adjudicate any dispute in connection with fulfilment of the official's contract. ${ }^{5}$

IFOs established their conflict resolution systems much later than their establishment dates, at least 25 years after the date each IFO was set up, with the exception of the European Bank for Reconstruction and Development (EBRD). EBRD was established in 1991 and took less than 10 years to have conflict resolution systems in place; by the 1990s, there was significant institutional practice in the development of conflict resolution systems in the other IFOs.

in each IFO: the WBG and AfDB use "ombudsman" while the ADB, IADB, IMF, and EBRD use "ombudsperson". The EBRD changed the term "ombudsman" to the gender-neutral "ombudsperson" in July 2011. Strictly speaking, the term "ombudsman" is a singular term of Swedish origin, where this term was first introduced over 300 years ago by the Swedish king in 1713 so that Swedish officials followed the law, and "man" refers to the responsibility to serve "the people" and does not signify singular/plural or gender. See WBG Ombuds Services 2007 Annual Report, Executive Summary.

$4 \quad$ United Nations General Assembly A/65/373 (16 September 2010) on Administration of justice at the United Nations, Report of the Secretary-General, 4.

5 Amerasinghe, C. F., The Law of the International Civil Service 2nd Revised ed. Vol I, (Oxford University Press, 1994), 54. 
Table 1.

Dates of establishment of conflict resolution mechanisms in International Financial Organisations and the United Nations

\begin{tabular}{|l|l|l|l|l|l|l|l|}
\hline & $\begin{array}{l}\text { World } \\
\text { Bank }\end{array}$ & IADB & ADB & IMF & AfDB & EBRD & $\begin{array}{l}\text { United } \\
\text { Nations }\end{array}$ \\
\hline $\begin{array}{l}\text { Establishment of the } \\
\text { institution }\end{array}$ & 1944 & 1959 & 1966 & 1944 & 1964 & 1991 & 1945 \\
\hline $\begin{array}{l}\text { Administrative Tri- } \\
\text { bunal }\end{array}$ & 1980 & 1981 & 1991 & 1994 & 1999 & 2002 & $1949 *$ \\
\hline $\begin{array}{l}\text { Appeals/grievance } \\
\text { system (for IADB, } \\
\text { conciliation com- } \\
\text { mittee) }\end{array}$ & 1977 & 1983 & 1987 & 1981 & 1990 & 1999 & $* *$ \\
\hline Ombuds function & 1980 & 1997 & 2012 & 1979 & 1992 & 1997 & $* * *$ \\
\hline Mediation function & 1999 & 2013 & none & 2012 & 2007 & none & $* * *$ \\
\hline $\begin{array}{l}\text { Current staff num- } \\
\text { bers**** }\end{array}$ & 15,000 & 2,000 & 2,600 & 3,000 & 1,500 & 1,500 & 41,000 \\
\hline $\begin{array}{l}\text { Ombudsperson (all } \\
\text { full-time, except } \\
\text { EBRD) }\end{array}$ & 3 & 1 & 1 & 1 & 2 & 1 & $12 * * * * *$ \\
\hline
\end{tabular}

ADB, Asian Development Bank; AfDB, African Development Bank; EBRD, European Bank for Reconstruction and Development; $I A D B$, Inter-American Development Bank; IMF, International Monetary Fund; UN, United Nations; World Bank; WBG, World Bank Group.

* The UN Administrative Tribunal was abolished as of 31 December 2009, following the UN General Assembly Resolution 63/253 Administration of justice at the United Nations (17 March 2009). Under this resolution, the formal system under the UN Administrative Tribunal was replaced by a two-tier system of the UN Dispute Tribunal followed by the UN Appeals Tribunal.

** The establishment of the new system of administration of justice saw the abolition of peerreview mechanisms of the old system effective 1 July 2009. See United Nations General Assembly A/65/373 (16 September 2010) on Administration of justice at the United Nations, Report of the Secretary-General, para. 5.

*** Under the new system of administration of justice, the integrated Office of the UN Ombudsman and Mediation Services (UNOMS) was established pursuant to UN General Assembly resolution $62 / 228$ on Administration of justice at the United Nations (6 February 2008). See United Nations General Assembly A/64/314 (20 August 2009) on Activities of the Office of the United Nations Ombudsman and Mediation Services, Report of the SecretaryGeneral, para. 6 .

**** Source: conference materials on file, annual reports, and websites.

***** The UNOMS is a combined office providing both ombuds and mediation services and this figure includes the 7 regional ombudsmen in the regional branches. See http://www. un.org/en/ombudsman/ombudsmenlist.shtml (accessed 27 June 2014). 
The main reasons for the late development of setting up of conflict resolution systems in the IFOs was that there were small staff numbers and that administrative settlement was a practical way in resolving employment disputes. For example, the World Bank had less than 1,000 employees in 1960, and today the number at the World Bank Group (WBG) is more than $15,000 .{ }^{6}$ ADB had less than 450 employees in 1969 , and today the number is more than $2,900{ }^{7}$ In these initial years, dealings with employment disputes between employees and the organisation were handled in practical ways through settlement on an ad hoc basis. But over the years, it was found that with the increase in the number of employees, together with cultural diversity, and the organisational and managerial structure of the IFO becoming more complex, settlement of disputes through a judicial body was in the interest of both the employee and the organisation. The reasons for establishing administrative tribunals in the IFOs were to provide these independent judicial bodies set up by the board of directors with procedures according fair hearing and due process to the claimant, and to avoid the possibility that national courts "could be induced to assume jurisdiction" in the absence of the institution having its own judicial body to resolve staff disputes.

\section{ESTABLISHMENT OF OMBUDS SERVICES IN THE IFOS AND ADB's APPROACH}

Turning over to informal processes, ombuds services were introduced in the 1960s in the USA in the American government, universities, and corporate organisations with a new meaning. These ombuds services were not to be viewed as had been initially the case where government established ombuds services ranging from investigating government officials for official wrongdoing to redressing citizen complaints against public officials, but were now extended to state and local

\footnotetext{
6 http://www.greeningtheblue.org/what-the-un-is-doing/world-bankgroup-wbg (accessed 27 June 2014)

$7 \quad$ Asian Development Bank Annual Report 2013.

8 This was one of the reasons given by the World Bank president for establishing the World Bank Administrative Tribunal. See Amerasinghe, C. F., The Law of the International Civil Service $2^{\text {nd }}$ Revised ed. Vol I, (Oxford University Press, 1994), 45.
} 
governments, colleges, universities, and corporations under the rubric "organisational ombudsman" ${ }^{\circ}$ with the key principles of independence, neutrality, confidentiality, and informality. IMF and the World Bank, both headquartered in Washington DC, USA, were the first two IFOs to incorporate and promote ombuds services in their respective conflict resolution systems. Unlike the World Bank, the IMF did not have its administrative tribunal at the time of the introduction of the ombuds services, and established its administrative tribunal five years later in 1994. Two other IFOs - IADB and EBRD - also introduced an ombuds function before establishing an administrative tribunal at least five years later. The reasons for IMF's introduction of an ombuds function stated in the memorandum from the Managing Director of the IMF to the staff dated 23 July $1979^{10}$ are instructive - that it has "long been recognized that some form of mechanism should be established in the Fund to deal with the individual grievances of staff members" and a study from the working group comprising members from the Administration department and representatives of the Staff Association Committee found that "an Ombudsman, complemented by a Committee to handle grievances, would best serve the needs of the Fund." (The grievance committee, to handle interpretation and application of the Fund's rules and regulations, as opposed to the ombuds function in being informal and settling problems relating to interpersonal relations, was created two years later in 1981.)

$9 \quad$ Howard, Charles L., The Organizational Ombudsman: Origins, Roles and Operation - A Legal Guide, chapter 2 (USA: ABA Publishing, Chicago, Illinois, 2010). These four principles are enshrined as the ethical principles in the International Ombudsman Association (IOA)'s Code of Ethics. The IOA - http://www.ombudsassociation. org/(accessed 27 June 2014) - is the largest international association of professional organizational ombudsmen practitioners in the world, representing over 500 members from the United States and across the globe. The IOA supports organizational ombudspersons worldwide working in corporations, universities, non-profit organisations, government entities and non-governmental organisations, including the UN Ombudsman and Mediation Services (UNOMS), and the ombuds offices and the mediation offices in all the IFOs. The UNOMS and the resolution or terms of reference of the ombudspersons in these IFOs espouse these four principles.

10 Managing Director, IMF's memorandum to staff members dated 23 July 1979 (copy on file). 
ADB was the last of the 6 IFOs to introduce ombuds services in its conflict resolution system, nearly 20 years after the establishment of its administrative tribunal. There had been prior discussions on setting up an ombuds function and the catalyst for its introduction was the Bank's "Our People Strategy" ${ }^{11}$ which defined the principles for the bank to improve its workplace environment. The establishment is a positive development by the institution in setting up various conflict resolution mechanisms in its efforts to improve and strengthen its internal systems in achieving an integrated conflict resolution management system. Such an integrated system involves many stakeholders such as human resources, ethics office, integrity office, staff association, and service providers such as ombuds, mediation, peer review, and administrative tribunal and takes time and studies as has been the case at the WBG and at the UN. ${ }^{12}$

Reform change is crucial in the implementation of conflict resolution mechanisms and does not happen overnight. The third WBG ombudsman was finally engaged in 2011 even though there was a recommendation from the Report of the Grievance Process Review Committee in 1998. The UN's review of its internal justice system took many years and found that a new system of justice administration was needed to replace "a largely peer-review system that had functioned for more than 60 years but which had become, in the view of the Assembly, 'slow, cumbersome, ineffective, and lacking in professionalism'."'13

In January 2010, ADB's Board of Directors approved the Bank's "Our People Strategy" defining the principles for the Bank to follow in recruiting, retaining, and developing staff and managers, and in improving its workplace environment. Under this strategy, a HR Strategic Framework and Action Plan was developed which specified initiatives to translate the strategy into practice. The

$11 \quad$ Our People Strategy, (ADB, November 2011) at http://www.adb. org/sites/default/files/publication/27521/our-people.pdf (accessed 27 June 2014), 25.

12 Nanwani, Suresh, "Conflict Resolution Mechanisms in International Financial Organisations: Experiences and Collaborations in Broadening the Informal Process", Global Policy, Vol 5(3) (2014) 381: 383-384.

13 United Nations General Assembly A/65/373 (16 September 2010) "Administration of justice at the United Nations", Report of the Secretary-General, p. 4. 
establishment of the ombuds function was one of these initiatives in pursuance of the strategy's goal of providing a "supportive and enabling workplace environment and culture." 14

ADB's experience in setting up its ombuds function is best summarised through the following two phases:

(1) A comprehensive study carried out by the Bank's Budget, Personnel, and Management Systems Department (BPMSD; the term "HR department" is used for convenience) and the Bank's Office of the General Counsel in consultation with various stakeholders from mid2010 to early 2011 ; and

(2) The process engaged by the Bank in recruiting an ombudsperson. The outcome was the adoption of an Administrative Order (AO) 2.14 (Ombuds Function) dated 27 April 2011 approved by the President on the policy for the provision of an ombuds function for staff members. The recruitment process was carried out through a search committee involving the Staff Council, and the first ombudsperson was appointed in January 2012.

Both phases involved the participation of stakeholders, primarily (i) the Staff Council representing the views of staff in the Staff Association; (ii) the Professional Women's Committee (PWC), ${ }^{15}$ representing the views of professional internationally-recruited women in the Bank who are also members of the Staff Association; and (iii) the Human Resources Committee (HRC) of the Bank's Board of Directors, set up in July 2009 to facilitate direction of the general operations of the Bank with regard to human resources (HR) management. The views of other stakeholders were also obtained and considered in the study, in particular, the views of departments

14 Our People Strategy, (ADB, November 2011) at http://www. adb.org/sites/default/files/publication/27521/our-people.pdf (accessed 27 June 2014), 25.

15 The Professional Women's Committee (PWC) was established in 1993 (renamed International Women's Committee in 2011) at the initiative of ADB women international staff to ensure fair and equitable work environment for women international staff and to provide networking and other support for women international staff. The PWC liaised with the Staff Council on issues of specific concern to women international staff and collaborated with the Staff Council in providing inputs in the study. 
and offices within the Bank, and of any individual staff member who wished to provide comments. The study lasted about 6 months.

One significant input throughout the whole process was the helpful and positive contribution, expressed both formally and informally, by the ombuds services of the 5 IFOs and of the UN Ombudsman and Mediation Services (UNOMS), ${ }^{16}$ during both the study and in the recruitment process. This was a critical resource as many stakeholders, including the Staff Council, PWC, and HRC, urged best practices of other comparator IFOs although best practices varied depending on the specific subject matter covered. The common denominators of best practices included the four cardinal principles of an organisational ombudsman - independence, neutrality, confidentiality, and informality - referred to above and these were expressly enshrined in the resolution setting up the ADB ombuds function. The "strategic position statement on ombudsmen" of the (United Kingdom) Ombudsman Association also articulates the following characteristics in the fundamental criteria for ombudsman (independence; fairness; effectiveness; openness and transparency; and accountability), and in the criteria on determining the success of the ombudsman model (independence; impartiality; free access; informal and flexible process; active investigation; and effective address). ${ }^{17}$

Apart from the key principles underpinning a professional

16 The key persons consulted included the following ombuds persons from AfDB, EBRD, IADB, IMF, WBG, and UNOMS: Amabel Orraca-Ndiaye; Alisand Singogo; Professor David Metcalf; Doris Campos-Infantino; Wilbur Hicks; Lois Petzold; Constance Bernard; Thomas Zgambo; and John Barkat. Other key persons consulted included Camilo Azcarate and Linda Toyo Obayashi from WBG's mediation services, and Mame Diagne and Helmut Buss from the Office of the Ombudsman for the United Nations Funds and Programmes.

17 See Ombudsman Association Annual Report (2012 to 2013), p. 11. The Ombudsman Association was formerly the United Kingdom Ombudsman Association which was formed in 1993 for ombudsman for the public services such as Local Government Ombudsman for England for complaints against local authority departments and agencies, and for the private sector for consumer goods and services such as the Financial Ombudsman Service for financial services firms. 
and credible ombuds function outlined above, the appointment of the ombudsperson was most important in the study as this had to suit the institutional context and the needs of the organisation and staff. On this, the practice varied in the IFOs. At EBRD, the ombudsperson's appointment was on a part-time basis, and the nature of this appointment continued after the bank's review in 2011. At IMF and other IFOs, the ombudsperson's appointment is on a full-time basis. However, the IMF ombudsperson had an initial two-year period which could be extended for a period of three years, while in the other IFOs, the initial period of appointment was more than two years.

InADB's case, the ombudsperson's appointment was made fulltime, as in the other IFOs excepting EBRD. The ADB ombudsperson's term is for a period not exceeding three years and the appointment is made by the President to whom the ombudsperson reports to (as is the case in all IFOs), after consultation with the Staff Council and the term may be renewable once, again after consultation with the Staff Council. The critical element factored in the study and the resulting policy, as well as the implementation of the ombuds function, was that there was no "one-size-fits-all" approach; the ombuds function needed to take into account the institutional needs and context, and also reflect the views of the staff. For example, there is no specific bar in the IFO resolutions creating the ombuds services on internal staff applying for ombudsperson positions. At the WBG and AfDB, the first ombudsperson was a bank staff but subsequent ombudspersons were externally-sourced (the WBG has three ombudspersons and AfDB has two). IADB's ombudsperson was appointed internally, but after a review in 2005, the ombudsperson was appointed externally. IMF is the only institution that has an externally-sourced person filling in the position since the ombuds function was created in 1979.

At ADB, an externally-sourced person was recruited as the first ombudsperson (and the second ombudsperson was also externally-sourced). The recruitment process has been by a search committee that includes a member from the Staff Council (usually the Chairperson). There is no golden rule on an express prohibition in organisational ombuds practice but what is important is that if a staff member is appointed as an ombudsperson, the person should be well-respected to ensure a professional and credible ombuds role; there should be effective management of conflicts; and importantly, there should be a post-employment bar from working with the organisation 
after the term. At the World Bank on its three existing ombudsperson positions, the first ombudsperson position was internally recruited (and that position has so far been an internal candidate), while its second and third ombudsperson positions (created in 1999 and 2011, respectively) have so far been externally recruited.

During the study, concerns were raised by the HRC about the risk of having an expensive bureaucracy and measures to encourage staff to utilise the ombuds function and remove any perception that staff could be subjected to reprisals. ${ }^{18}$ Establishing a new office (on staff matters, in this instance) in an organisation involves cost to the organisation, and importantly, buy-in from all stakeholders. At ADB, the ombuds office was created with a full-time ombudsperson supported by two full-time staff to support the ombudsperson on activities such as outreach and communication, and this institutional arrangement is similar to the WBG, and fares better than other IFOs such as IMF, where the ombudsperson shares an assistant with another dispute resolution office, and EBRD, where the part-time ombudsperson is provided meeting room facilities but has to arrange secretariat support.

The ADB ombuds function has a feature distinctive from those of the other IFOs in that it expressly provides for a review by the bank in consultation with the Staff Council in the first quarter of the third year of the ombuds operations. This specific review provision would enable parties to give their inputs in making any enhancement to the ombuds function. The first ombudsperson was appointed in January 2012 for a three-year term but the term ended in May 2013 as the ombudsperson left for unforeseen personal and family-related circumstances. The bank carried out the recruitment process for a new ombudsperson and appointed the current ombudsperson in December 2013.

18 Annual Report of the Human Resources Committee (2010-2011), ADB's Board of Directors Human Resources Committee (August 2011). 


\section{SUGGESTIONS FOR MOVING FORWARD OF THE OMBUDS OFFICES IN THE IFOS AND THE LESSONS LEARNED FOR OTHER IFOS}

The ADB experience in establishing its ombuds services benefitted from the experience gained and reviews made by its comparator organisations and from developments in best practice advocated by the International Ombudsman Association (IOA). With all the 5 IFOs now having an ombuds function, and some IFOs like the World Bank, IMF, and IADB having moved further in informal dispute resolution in their internal justice systems (through the establishment of mediation services), the heads of the ombuds and mediation offices may consider having annual meetings to exchange views through heads of ombuds and mediation offices, just as IFO heads of personnel departments, legal departments, accountability mechanisms, evaluation departments or procurement meet every year or regularly. This will give the ombuds and mediation services of each IFO a dedicated and common platform to share their ideas and consider latest developments for strengthening the informal process in the internal justice systems of their organisations. Currently, ombudspersons and mediators in the IFOs who are members of the IOA usually attend the annual IOA meetings in their individual capacities as members of the professional association supporting organisational ombudsmen, but this does not necessarily cover all the ombudspersons in the IFOs. The United Nations and Related International Organisations (UNARIO) group chaired by the UN Ombudsman, UNOMS is usually held every year since its first meeting in 2003, and is focused on sharing best practices, engaging in professional development, and networking with colleagues. Participation at these UNARIO meetings also includes many other different organisations such as the International Labor Organisation and the International Civil Aviation Organisation, and the ombudsperson and mediators of the IFOs may alternatively consider using the UNARIO annual meetings to include discussion of specific topics of interest common to these organisations.

Experience has shown that a full-time ombudsperson is important for a variety of reasons including, importantly, the institution's commitment in ensuring that, at all times, an ombudsperson is readily available to address staff concerns. Currently, the EBRD is the only institution that has a part-time 
ombudsperson. The review in 2010 considered the need for a full-time or part-time person, and resulted in the retention and continuation for a part-time ombudsperson with a term of 3 years and an extension of up to 2 years, retaining the previous requirement that no current or former staff member of the Bank could apply for that position. The provision of a part-time or full-time ombudsperson, or more than one ombudsperson, is again an institutional decision, and regular reviews with the participation of the staff association will ensure the efficient functioning of the system.

The ADB ombuds function is unique from the ombuds services of the other IFOs in that it has a specific provision on a review to be carried out in the first quarter of the third year of the operation of the ombuds function. Other IFO resolutions on their ombuds function are silent on a review as in the case of the WBG, although the WBG's 2002 organisational review of the internal justice system included review of the ombuds services. Other IFO resolutions provide for a review of the terms of reference of the ombudsperson but have no specific timeframe, as in the case of EBRD. A time-bound provision for a new function was found timely in this instance given that the ADB had established a new function, and a review would help assess the efficacy of the system in the institution's internal justice system. This provision on a specific review would help other IFOs having a new or revised ombuds function.

Publication of annual reports by the ombuds services is a matter that the IFOs, except AfDB, have yet to address. In 2012, the AfDB Office of the Ombudsman and Mediator made its annual report publicly available. ${ }^{19}$ This is in line with good practice as established by the UNOMS which has published its activity reports annually and these are made publicly available. ${ }^{20}$ With other international

19 African Development Bank Group, Office of the Ombudsman and Mediator (2012 Annual Report), available at http://www.afdb.org/ fileadmin/uploads/afdb/Documents/Procurement/Corporate-Procurement/ 2012\%20Annual $\% 20$ Report $\% 20$ of $\% 20$ the $\% 20$ Ombudsman $\% 20$ Office.pdf (accessed 27 June 2014)

$20 \quad$ See the United Nations General Assembly A/68/158 (18 July 2013) Activities of the Office of the United Nations Ombudsman and Mediation Services, Report of the Secretary-General available at http://www.un.org/en/ga/search/view_doc.asp?symbol=A/68/158 (accessed 27 June 2014) 
organisations also making their annual ombuds report publicly available such as the Office of the Ombudsman for the United Nations Funds and Programmes ${ }^{21}$ and the European Council for Nuclear Research $(\mathrm{CERN}),{ }^{22}$ there is a growing practice in the disclosure of annual ombuds and mediation reports. CERN created its full-time ombuds position in 2010 for the well-being of CERN's collaborators and for the improvement of practices affecting the workplace environment. With the increasing emphasis on public disclosure of ombuds annual reports, this could have an impact on the current practice by organisations not publishing their annual ombuds reports.

The duration of the ombudsperson's services is also a matter that has recently been considered by the IFOs. In 2009, the WBG amended its rules allowing one renewal of the 5-year term of the ombudsperson for an additional 5-year term to increase the position's attractiveness to potential applicants and also to take advantage of the institutional knowledge gained by the ombudsperson during the initial term. Other IFOs such as EBRD, IMF and ADB have not adopted this route. EBRD, in its 2011 review, continued with its previous position that the ombudsperson's term of appointment could be extended after consultation with the Staff Council by up to 2 years. At IMF, the ombudsperson will not be reappointed, and the total term of office will not exceed 5 years. At ADB, the ombudsperson's initial term of office does not exceed 3 years and the term may be renewable once, after consultation with the Staff Council. The key factors are the institutional needs and staff views (through the Staff Council), and the balance in providing the comfort zone to address these two concerns. Except for WBG and EBRD, all ombudspersons have a permanent bar of re-employment. WBG allows the ombudsperson to be reemployed, after a 2-year cooling-off period, for short-term

$21 \quad$ See the Report of the Office of the Ombudsman for the United Nations Funds and Programmes (UNDP, UNFPA/ UNICEFUNOPS) from 1 January 2010 to 31 December 2010 available at http://www.un.org/en/ombudsman/ jointombudsperson/pdf/2010 jointombudsperson_en.pdf (accessed 27 June 2014)

22 See the $2^{\text {nd }}$ annual report of the CERN Ombuds (1 July 2011 to 30 June 2012) available at http://ombuds.web.cern.ch/sites/ ombuds.web.cern.ch/files/Ombuds\%20annual\%20report\%20201112.pdf (accessed 27 June 2014) 
consultant appointments limited to the ombuds services and mediation services, provided that approval is given by both the President and the Staff Association. At EBRD, the bar on ineligibility for employment in the institution is a 5-year cooling-off period and is not permanent. The compelling argument here is that the independence and impartiality of the ombudsperson is preserved by the bar on re-employment though there are instances of re-employment possibility but within limits that strike an appropriate balance for the institution and staff to ensure a credible ombuds system.

Since 2000, the internal justice systems of WBG and IADB have gone through organisational reviews (in 2002 and 2011, respectively). There have been revisions to the ombuds services at EBRD (2011) and AfDB with the change of name to Office of the Ombudsman and Mediation (2013). Meanwhile, ADB created its ombuds function (in 2011), and IMF introduced a mediation function (in 2013). The UN established its ombuds office in 2001 and since 2009, the UNOMS has been an integrated office with ombuds and mediation services.

\section{CONCLUSION}

Within this context of review of informal dispute resolution processes, the lessons learned by various institutions offer valuable insights for other IFOs in conducting organisational reviews or in introducing new informal processes in conflict resolution mechanisms such as ombuds services or mediation services. The most significant lesson gained is the synergy from internal perspectives by the institution's staff, management, and the Board of Directors; and from external perspectives provided by experts (firms or individuals) in organisational review with expertise in internal justice system and dispute resolution, by associations of professional organisational ombuds or other ombuds associations, and by other comparator institutions having their internal justice system. These various views foster a conducive ombuds system in an international organisation that is current with best practices. 